\title{
Demystifying the International Criminal Court (ICC) Target Africa Political Rhetoric
}

\author{
Torque Mude \\ Department of Politics and Public Management, Midlands State University, Gweru, Zimbabwe \\ Email:mudetorque@gmail.com,mudet@msu.ac.zw
}

How to cite this paper: Mude, T. (2017). Demystifying the International Criminal Court (ICC) Target Africa Political Rhetoric. Open Journal of Political Science, 7, 178-188.

http://dx.doi.org/10.4236/ojps.2017.71014

Received: December 12, 2016

Accepted: January 22, 2017

Published: January 25, 2017

Copyright $\odot 2017$ by author and Scientific Research Publishing Inc. This work is licensed under the Creative Commons Attribution International License (CC BY 4.0).

http://creativecommons.org/licenses/by/4.0/ cc) (i)

Open Access

\begin{abstract}
The ongoing debate on the ICC's selective application of international criminal law targeting Africans has had negative implications on the international court and the law it applies. As a consequence of the political rhetoric that the ICC targets Africa, African leaders and their sympathisers have tended to view the court with contempt and some have expressed intentions to withdraw their membership of the court. Against this background, this paper examines the argument that the ICC targets Africa which amounts to an affront to international criminal law and its objective to end impunity to achieve international justice. The conclusion drawn from this study is that the assertion that the ICC targets Africa is a mere political rhetoric that warrants demystification. It is a political rhetoric advanced by African leaders to manipulate their way out of the responsibility to be accountable to international criminal law. Furthermore, the notion that the court targets Africans lacks substantive credibility as it ignores several structural and technical underpinnings such as the jurisdictional triggers, the role of the United Nations Security Council (UNSC) and other functional modalities that guide the operation of the court. Data for this paper were gathered from journal articles, organisational reports and documents, newspapers, case reports, treaties and other online sources.
\end{abstract}

\section{Keywords}

International Criminal Court, Political Rhetoric, Africa, Target

\section{Introduction}

The establishment of the ICC in 2002 was celebrated as a phenomenal achievement in the quest for ending impunity and attaining international justice. African countries especially Rwanda were part and parcel of those that celebrated the court as a milestone at the Rome Conference that launched the court. Less than a decade of the operation of 
the same international court, the same African countries have launched a political onslaught against the court calling it a political and fraudulent institution; because it has indicted, investigated and prosecuted only Africans since its formation. The criticism has culminated in the expression of intentions to withdraw membership of the court by almost all African countries that are state parties to the Rome Statute that created the court. It is important to demystify the popular political rhetoric that the ICC targets Africa as this has led to the irrational, reckless and unwarranted criticism of the ICC.

At first glance, one could be tempted to go along with the bandwagon of hysterics that view the ICC as a Western political machination designed to disproportionately punish Africans. The fact that only Africans have been indicted, investigated and prosecuted by the court is arguably suggestive of the court's selective application of international criminal law against African individuals. Be that as it may, a careful scrutiny of the international court reveals that the assertion that the ICC targets Africa is misguided and legally unfounded given the structural and technical issues that characterise the configuration of the court. Prior to getting into the quintessence of the matter under discussion, it suffices to trace the background of the relations between the ICC and African states. Such a background is essential in expounding how the court has related itself with the continent since its establishment.

\subsection{Background to the ICC-Africa Relations}

To comprehend relations between the ICC and African countries it is imperative to highlight the frequency of membership of the Rome Statute among African states, an overview of the court's caseload in Africa vis-à-vis other continents and reasons thereof and how African states perceive the court. Furthermore, it is important to examine the influence of national interests in the generation of the "ICC targets Africa" rhetoric. This background suffices to explore the validity of the argument that the ICC targets Africa.

From the onset, African states were fully behind the establishment of the ICC. African states actively participated in the 1990s negotiations that resulted in the adoption of the Rome Statute and the subsequent formation of the court (du Plessis, Maluwa, \& O'Reilly, 2013: p. 3). Hence, the creation of the ICC had the support of African governments. Ironically, African states are now lamenting over the African bias of the ICC when they took part in the negotiations that led to the adoption of the Rome Statute of the ICC. Could it be because they were cheated? How so? It is not possible that they were cheated because the Rome Statute is clear on the jurisdiction of the ICC. Articles 12 and 13 highlights that the court exercise jurisdiction on the basis of the nationality and territoriality principles as well as in instances where the United Nations Security Council (UNSC) refers situations of heinous crimes to the ICC (Rome Statute: Articles 12 and 13) for the exercise of universal jurisdiction. The involvement of the UNSC in the affairs of the ICC should perhaps be an issue of serious concern to African states since they are not directly represented in the UNSC.

Moreover, Africa has the highest frequency of state parties to the Rome Statute of the ICC. Of the 124 state parties to the ICC, 34 are African states. Hence, African states constitute more than one quarter of the total state parties. With 54 countries making up 
the African continent, it can be argued that the number of African states that are parties to the ICC speaks volumes of their initial perceptions of the international court. There is no doubt that having nearly three quarters of the whole continent part of the ICC illustrates that the African continent had a normal relationship with the court at its inception in 2002. It also illustrates the commitment of African states to the achievement of international justice through the ICC.

Unfortunately, the growth of skepticism against the court has resulted in submission of notices of withdrawal from the court by South Africa and Burundi in October 2016. The decision by these countries to leave the court could lead to a mass exodus from the ICC by other African states (Human Rights Watch Report, 2016) which could result in the commission of heinous atrocities in Africa with impunity. Already other African countries including Rwanda, Uganda, Malawi, Zimbabwe, Kenya, Gambia and the rest of African Union member states except Botswana have expressed displeasure about the conduct of the court in relation to its alleged selective application of international criminal law. Of all the 54 Africa states, only Botswana has defended the ICC. Through its foreign affairs ministry, the government of Botswana publicised its backing of the court saying it "regrets" the decision by South Africa to leave the court (News 24, 26 October 2016).

Even though this is not the focus of this paper, the decision taken by Botswana to defend the ICC when the rest of African states are expressing disdain for the court warrants interrogation. From what this researcher has observed over the past years, Botswana has always isolated herself from the rest of African states and sympathises with Western states when it comes to issue of human rights, governance and the respect of fundamental norms of the international community. For instance, only Botswana has publicly and confidently condemned the clinging on to power by the Zimbabwean president Robert Mugabe arguing that the leader's advanced age has made him incapacitated to competently rule the country (Zimbabwe News, 16 September 2016). Judging from Botswana's stance towards governance in Zimbabwe and South Africa's intentions to pull out of the ICC, Botswana appears to represent liberal democracy in Africa. This is contrary to skepticism that Botswana is a Western stooge. It can be argued therefore that Botswana is the only African state that openly acknowledges seeing the bigger picture in the ICC's relations with Africa.

Political interests are another important variable that has shaped ICC-Africa relations. The ICC has been criticised for being utilised by Western states in the pursuit of their selfish political interests in Africa. The Rwandan President Paul Kagame and Foreign Minister Louise Mushikiwabo view the ICC a "political court" and "fraudulent institution" (Lamony, 2013). Gambia has labeled the ICC a "Caucasian" court and the Kenyan leader Uhuru Kenyatta criticised the court for "pursuing weak, politicised cases" (Aljazeera News, 28 October 2016). Even though there are indications that the ICC has focused more on Africa, arguing that the court's focus on Africa amounts to the utilisation of the court for the pursuit of Western interests is fallacious given the magnitude of human rights violations in Africa. Instead of celebrating the achievements of the ICC in Africa and working towards restructuring the UNSC to create the pathway for prosecuting the likes of George Bush and Tony Blair for war crimes committed in 
Iraq in $2003^{1}$, African leaders are bent on pulling out of the court to mask their human rights abuses committed in the pursuit of their political interests.

It can be argued therefore that the onslaught peddled by African states on the ICC is mere scapegoat to manipulate their way out of accountability and transparency on human rights accountability. In other words, by wanting to pull out of the ICC African states are considering their political interests superior to international justice. For instance, Rwanda began to criticise the court when Belgium issued an arrest warrant for the then Democratic Republic of Congo (DRC)'s Foreign Affairs minister, Abdoulaye Yerodia Ndombasi in year 2000 under the auspices of the Rome Statute (International Court of Justice: DRC v Belgium Warrant Arrest Case: Case No. 11/2000). The matter led to the arrest warrant case in the International Court of Justice (ICJ) between Belgium and DRC in April 2011. Recently, Burundi also began to criticise the court and submitted intentions to withdraw from the court when evidence of human rights abuses against Pierre Nkurunziza attracted the attention of the ICC in 2015. It suffices to mention that African leaders have a tendency of unleashing violence upon their opponents just to keep power. And when they are accused of human rights violations they invoke sovereignty or dismiss efforts for the investigation of their conduct as having been engineered and sponsored by Western states. That explains Burundi, Rwanda, Kenya and Gambia's attacks on the ICC. The next section examines the roots of the accusations of the ICC's bias against Africa.

\subsection{The Roots of the "ICC target Africa" Criticism}

The demonisation of the ICC by African states has its roots in the early years of the court when African states became concerned about the erosion of sovereign immunity following Belgium's attempts to arrest DRC's minister. Sovereign immunity is a legal doctrine that prevents government officials from arrest and prosecution without the consent of the government of the officials in question (The Free Dictionary Online). It is based on the English law maxim, "the King can do no wrong" (Chemerinsky, 2001). In the view of the Rwandan government, Belgium's issuance of the arrest warrant for its foreign affairs minister, Abdoulaye Yerodia Ndombasi, was an affront to sovereign immunity. Indeed, Belgium's actions undermined the basic principle of sovereign immunity. This sparked the criticism of the ICC by Rwanda and the African Union. However, during the early stages of the criticism there was no consensus among African states as to what measures to take against the court.

Germany's arrest in November 2008 of Rose Kabuye, President Paul Kagame's Chief of Protocol (Wallis \& Hollinger, 2008), for shooting down then Rwandan President Juvenal Habyarimana's jet in the course of events that triggered the 1994 Rwandan genocide. The arrest triggered the AU's reaction as it adopted a resolution declaring that Western states were abusing and misusing the doctrine of universal jurisdiction to hunt Africans (AU Commission Report XIIII, 2008). The bloc also requested African states not cooperate with the European Union (EU) states that unprocedurally issue warrants

${ }^{1}$ The problem with advocating the prosecution of Tony Blair and George is the Chilcot Report or the Iraq War Inquiry Report in which the ICC denied jurisdiction over the UK and USA's decision to invade Iraq. However, the court agreed to investigate UK and USA soldiers for human rights abuses committed during the invasion of Iraq. 
of arrests against Africans (Ibid). The involvement of the AU in the Rwandan issue illustrates the extent to which African states began to speak with one voice with regard to the conduct of Western states in using universal jurisdiction. Hence, ICC-Africa relations began to sour in 2008 .

However, it can be argued that the decision adopted by AU against the arrest of the Rwandan official was more reactionary than rational and logical. Since the individual in question had committed war crimes, there was nothing sinister in Germany arresting the individual. In fact, Germany's actions were in the interests of international justice. Astonishingly, instead of celebrating Germany's assistance in apprehending an international criminal, the AU was quick to support Rwanda. It can be argued that the AU's response to the arrest illustrates the questionability of Africa's commitment to international justice. It can also be argued the reaction of the AU should be understood in the context of neo-colonialism skepticism by African states as they often interpret actions by Western states as having imperialist motives. This is due to the history of colonial relations between European and African countries; almost all African countries were under colonial rule from the last decade of the nineteenth century until the last decade of the twentieth century.

Apart from the Rwandan issue, the ICC's issuance of a warrant to arrest the Sudanese President, Omar al Bashir, in March 2009 sparked outrage over the abrogation of diplomatic immunity. According to du Plessis et al, the issuance of the arrest warrant for Omar al Bashir was the "watershed moment for the AU's relationship with the ICC" (du Plessis et al., 2013) as it worsened the already shaky relations between Africa and the international court. The arrest warrant was in accordance with Article 27 of the Rome Statute which dismisses official capacity as grounds for immunity from arrest and prosecution (Rome Statute: Article: Article 27). At first glance, it can be concluded that it was unfair for the ICC to issue an arrest warrant for a sitting head of state when diplomatic and sovereign immunity protect heads of states from prosecution. Furthermore, it can be concluded that Article 27 of the Rome Statute was designed to spearhead a witch hunting exercise for African leaders. However, from a liberal point of view Article 27 works in the interests of humanity as it bypasses diplomatic immunity to cater for the prosecution of human rights violators. Hence, the provision is a necessary even though it abrogates sovereign immunity.

In continuation of the above, instead of complaining about the erosion of sovereign immunity African states should rather pressurise for the reformation of the ICC to investigate human rights violators from other continents including Europe including Tony Blair and George Bush over the Iraq war. Even though Bush and Blair are off the hook due to the Chilcot Report in which the ICC dismissed having jurisdiction over Bush and Blair's involvement in the Iraq War, African states could lobby for the intervention of the UNSC to have the two indicted. However, any attempt to indict the two through the UNSC is fraught with limitations because both the UK and USA are part of the five permanent members of the UNSC and in any case France being an ally to these two may veto any resolution against the UK and USA. Be that as it may, the reformation of the ICC and the UNSC should be the topical issues among African states than attacking the ICC for prosecuting perpetrators of human rights violations in Africa. 
Moreover, the indictment of the Kenyan President Uhuru Kenyatta and his deputy William Ruto in 2013 over allegations of crimes against humanity allegedly committed in the 2007-2008 post-election violence in Kenya (International Criminal Court: Prosecutor $v$ Uhuru Mugai Kenyatta: Case No. ICC 01/09-02/11) in which approximately 1200 people died (Aljazeera News, 28 October 2016). The Kenyan president became the first ever sitting head of state to appear before the ICC. Kenyatta's case collapsed, but his deputy's case has not been concluded. Even though the Kenyatta's case collapsed in 2014 due to lack of evidence, Kenya took the matter to the AU to discuss a strategy for the withdrawal of African states from the ICC. The Kenyan case further deteriorated ICC-Africa relations to the extent that all African states except Botswana began contemplating with conviction withdrawal from the court. In 2015, the then AU chairman Robert Mugabe asserted that the ICC was not welcome in Africa (Aljazeera America News, 2015).

Having explored the roots of the criticism of the ICC, the rationality of African countries withdrawing their membership of the ICC can be put into question. Ironically, it appears that what African countries are complaining about is not worth complaining. They are against the attainment of international justice on the continent. Hence, they seem to be prioritising the welfare of the political elites at the expense of international justice and human rights accountability.

A human rights violations background check of African leaders who have been on the forefront of opposing the ICC's work in Africa depicts hypocrisy, dishonest and chicanery. Kenya, Zimbabwe, Gambia, Rwanda, Burundi and Sudan all have bad human rights records. Having said that, it can be argued that the calls to exit the ICC by these countries is fraught with subterfuge as African leaders are trying to manipulate the continent out of compliance with international criminal law so as to exonerate African leaders from the responsibility of human rights accountability. At this juncture, it is imperative to explore the magnitude of international crimes in Africa. The purpose is to examine the justification for the court's exerted focus on Africa more than other parts of the world.

\section{The Magnitude of International Crimes in Africa: Justifying the ICC's Focus on the Continent}

There is little doubt that wars crimes, crimes against humanity and genocides are endemic on the African continent. Ranging from coup détats to terrorist problems, the continent is plagued with wanton human rights violations to the extent that attracting the attention of the ICC is inevitable. Lack of an African court with jurisdiction to try international crimes has made the ICC the only hope for fighting impunity on the continent. The African Commission of Human Rights and African Court of Justice and Human Rights have no jurisdiction to try international crimes. Apart from lack of jurisdiction over international crimes, the judicial bodies have no commitment to be involved international crimes. Had it been committed, it could have made headway through its own jurisprudence the same way the East African Court of Justice became a successful self-proclaimed human rights court (Gathii, 2013: p. 250) through jurisprudence created in the Katabazi case. To examine the magnitude of international crimes 
in Africa with a view to validate the ICC's focus on Africa, four case studies namely Rwanda, Burundi, Kenya and Democratic Republic of Congo are explored seriatim.

First, the Rwandan genocide was one of the worst international crimes in Africa. The establishment of the International Criminal Tribunal for Rwanda in the aftermath of the genocide was a clear indication of the gravity of the events of 1994 in Rwanda. Pursuant to that, Germany's arrest, through universal jurisdiction, of Rose Kabuye in 2008 for complicity in the assassination of the then Rwandan leader Habyarimana in the wake of the genocide should be worth commendation than rebuke. The logic behind Rwanda's criticism of the ICC vis-à-vis the Kabuye incident is not convincing given the palpability of the Rwandan genocide internationally. Therefore, Rwanda's criticism of the ICC is more politically motivated than it is driven by concern of the court's partiality. It is politically motivated because the arrest compromised the state's interests and the sovereign immunity of the Rwandan government official. In the final analysis, it can be argued that the outcry over the alleged ICC's bias against Africa is mere political rhetoric which is regrettable given the imminent mass exodus of African states from the ICC due to the precedence South Africa and Burundi set.

Second, there is substantial evidence that crimes against humanity were committed in the post-2007 election violence in Kenya. The widespread ethnically motivated violence that followed the 2007 elections in Kenya resulted in the death of 1000 people and displacement of approximately 500,000 civilians (International Coalition for the Responsibility to Protect, Nd). The International Coalition for the Responsibility to Protect (ICRtoP) reported that the 2007-2008 Kenyan political crisis was characterised by ethnically motivated killings across the Party of National Unity (PNU)-Orange Democratic Movement (ODM) political divide (Ibid). It is alleged that the Kikuyu sympathisers of PNU targeted the Luo, Luhya and Kalenjin ethnic groups who were backing opposition ODM and vice versa (International Coalition for the Responsibility to Protect, Nd). To qualify these killings as crime against humanity, it suffices to make reference to the Rome Statute of the ICC. The Rome Statute is the ultimate source of international criminal law.

Article 7 of the Statute conceptualise crimes against humanity as enumerated acts including murder, rape, enforced disappearance, torture and other inhuman acts committed intentionally (Rome Statute: Article 7). Therefore, the 2007 political violence in Kenya constitutes crimes against humanity. Consequently, the ICC was justified to institute investigations against and indict Uhuru Kenyatta and William Ruto. However, it is surprising that the ODM leader Raila Odinga who also had a hand in the counter-attacks directed on PNU supporters was spared by the ICC. One would wonder why? Could this be an instance of partiality? An attempt to comprehend the reasons would tempt one to suspect selective application of the law. Arguing along those lines could be backed by the political rhetoric that ODM is a Western sponsored party designed to effect regime change in Kenya. Hence, because of the court's Western alignment, the ICC could not investigate or prosecutor an ally of the West.

In continuation of the above, it is such narrow perspectives that have given rise to the demonisation of the ICC. Since the evidence of the commission of crimes against humanity in Kenya is there, the investigation and indictment of William Ruto and Uhuru 
Kenyatta using universal jurisdiction should be accepted as part of progressive efforts at achieving international justice. However, the politicisation of investigations and prosecutions by the ICC cannot be ruled out due to the court's Western alignment.

Third, there is no need for rocket science to convince one of the war crimes committed by the Omar al Bashir regime in Darfur beginning in year 2003. The conflict followed Sudan Liberation Movement (SLM) and Justice and Equality Movement (JEM) rebel groups' tension with the Sudanese government as the rebel groups accused the government of oppressing non-Arab people in Darfur (BBC News, 8 February 2010). In response, the Bashir government through the Janjaweed militia conducted ethnically motivated killings of non-Arabs in Darfur resulting in the death of approximately 300, 000 people and the subsequent indictment of Bashir by the ICC in 2009 for genocide, crimes against humanity and war crimes (Ibid). Judging by this, the issuance by the ICC of the arrest warrant against Omar al Bashir was justifiable.

However, questions can be raised in relation to the increasing trend of bypassing sovereign immunity in the exercise of universal jurisdiction by the court. Even though international crimes were committed in Sudan, wanting to arrest a sitting head of state is an affront to acceptable principles of sovereign immunity. However, if the intentions of bypassing sovereign immunity are solely for the attainment of international justice, the ICC should be commended for the remarkable effort. Nevertheless, if the intentions are political as purported by African leaders then something should be done to stop the ICC's hunt for Africans. Perhaps the court should be reformed to do away with its selective application of the law. Nonetheless, that the ICC is targeting Africans only is mere political rhetoric because non-African states have been on the ICC radar. For instance, there are ongoing preliminary examinations in Afghanistan, Ukraine, Colombia, Iraq and Palestine. Honduras, Venezuela and Korea were also once under preliminary examinations. If this is anything to go by, it is inapposite for African leaders to argue that they have been disproportionately targeted by the court.

Forth, Burundi is under preliminary investigation for the death of more than 430 persons, the arrest of approximately 3400 people and displacement of about 230,000 Burundians due to the conflict that erupted in the country since April 2015 (International Criminal Court Focus, 2015). The preliminary examination of Burundi in respect of acts of killing, torture, rape, enforced disappearance and imprisonment committed in Burundi by Pierre Nkurunziza's government (Ibid) was justified. There is no doubt that these acts constitute international crimes. Hence, the ICC's focus on Burundi is justified. The backlash by the Burundi government that has seen the state's issuance in October 2016 of intentions to leave the ICC can therefore best be comprehended in political terms. How convenient could it be that Burundi notified its intentions to leave the ICC when it is under investigations? It can be argued that Burundi's intentions to leave the ICC are marred by political considerations especially the desire to escape transitional justice responsibilities.

The four cases examined above are just a reflection of the extent of the commission of international crimes in Africa which has inevitably attracted the attention of the ICC. Other cases of egregious human rights violations include torture, intimidation and harassment of opposition party leaders and supporters during election times in Zimbabwe, 
human rights abuses in the Central African Republic, Mali, Niger Delta, Gambia and Nigeria among other others. Given the record of the occurrence and recurrence of conflicts, sporadic political violence and concomitant human rights abuses in Africa, it is not surprising to have the ICC focus on Africa. In response to being targeted, it is equally not surprising to have African leaders criticise the court, threaten to withdraw their membership and calling the court of sorts of demeaning names. In most cases, African leaders make it appear as if individuals from other continents especially Europe have been spared by the court.

Perhaps it could be fair to explore the extent of the commission of international crimes in Europe in relation to the reaction of the ICC thereof. Juxtaposing the magnitude of international crimes in Europe and the ICC's focus on the European continent would go a long way in examining the credibility of the critique that the ICC target Africa. The Human Rights Watch World Report of 2015 highlights that traces of human rights abuses in Europe in 2014 were noticeable. The report summarises the prevalence of racial discrimination and ethnic intolerance in Italy, France, Poland and Germany, ethnic problems in Hungary, intolerance to disability, migrants and same sex marriages in Croatia, Greece and Netherlands and the UK's complicity in overseas torture (World Report, 2015). Of the criteria of human rights abuses recorded in Europe none of them fall within the jurisdiction of the ICC except for war crimes and crimes against humanity committed during the Ukrainian crisis which began in November 2013. As for Ukraine, a preliminary examination by the ICC is ongoing. Hence, it can be argued that the ICC targets any country whose adherence to international criminal law is questionable.

African leaders including the Zimbabwean president Robert Gabriel Mugabe has more often indicated the need to have Tony Blair and George W Bush prosecuted by the ICC for war crimes and crimes against humanity committed in the 2003 Iraq War. Whilst it might appear as if the ICC has a case against Bush and Blair, the Chilcot Report made it clear that the ICC does not have jurisdiction over the US and UK's decisions to wage war on Iraq, but stressed the need to investigate soldiers who committed the crimes in the war. While the report may be accepted as binding, it raises eyebrows as to how and why the soldiers would be investigated independent of the two leaders, Bush and Blair, who sanctioned the war. Be that as it may, questioning the Chilcot Report is tantamount to unnecessarily challenging international public policy and decisions.

It goes without saying that criticising the court or withdrawing membership is not a noble solution; a non-confrontational approach would work. Withdrawing membership because of the political rhetoric will be a setback for international justice. Africa on its own has no court to prosecute international criminals and the continent is a theatre of intra-state conflicts, sporadic violence and wanton human rights abuse such that it needs the ICC to foster transitional justice.

\section{Conclusion}

The assertion that the ICC targets Africa is an unprecedented political rhetoric which has regrettably made African states to look at the court with the scorn it does not deserve. 
It appears that maggots of human rights abuses in Africa are the ones at the forefront of demonising the court. The intentions of these countries are arguably to mobilise other African states to express disdain for the court and subsequently collectively withdraw from the court. The political rhetoric has succeeded as South Africa and Burundi submitted their notices of intentions to pull out of the ICC. It remains to be seen what the future holds in so far as the future of the relations between the ICC and Africa, but one thing is clear; the political rhetoric that the ICC targets Africa has turned African states against the court.

\section{References}

Aljazeera America News Online (2015). Mugabe Says ICC Unwelcome in Africa. Aljazeera America, 16 June 2015.

http://www.america.aljazeera.com/articles/2015/6/16/mugabe-says-ICC-unwelcome-in-africa. $\underline{\mathrm{html}}$

Aljazeera News Online (2016). ICC Debate: Africa v Infamous Caucasian Court. Aljazeera, 28 October 2016.

http://www.aljazeera.com/news/2016/10/icc-debate-africa-infamous-caucasian-court-1610281 $\underline{42708060 . h t m l}$

AU Commission Report (2008). Decision on the Report of the Commission on the Abuse of the Principle of Universal Jurisdiction, EX CL 411/XIIII.

BBC News (2010). Q\&A: Sudan’s Darfur conflict. BBC News, 8 February 2010. http://news.bbc.co.uk/2/hi/africa/3496731.stm

Chemerinsky, E. (2001). Against Sovereign Immunity. Stanford Law Review, 53, 1201-1224. (quoting Sir William Blackstone).

https://scholarship.law.duke.edu/cgi/viewcontent.cgi?article=1685\&context

Democratic Republic of Congo v Belgium Arrest Warrant Case 11/2000. http://www.icj-cij.org/docket/index.php?p1=3\&p2=3\&case $=121 \& p 3=4$

du Plessis, M., Maluwa, T., \& O’Reilly, A. (2013). Africa and the International Criminal Court. London: Chatham House.

Gathii, J. (2013). Mission Creep or a Search for Relevance: The East African Court of Justice's huMan Rights Strategy. Duke Journal of Comparative and International Law, 24, 249-294.

Human Rights Watch World Report (2015). European Union: Events of 2014. http://www.hrw.org/world-report/2015/country-chapters/croatia-european-union-france-ger many-greece-hungary-italy

Human Rights Watch (2 November 2016). Africa Speaks out against ICC Withdrawal. http://www.hrw.org/Africa/Botswana

International Criminal Court Focus (2015). Alleged Crimes under the ICC's Jurisdiction Committed in Burundi since April 2015.

Lamony, S. A. (2013). Rwanda and the ICC: Playing Politics with Justice. African Arguments. http://africanarguments.org/2013/10/21/rwanda-and-the-icc-playing-politics-with-justice-by-s tephen-a-lamony

News24.com. (2016). Botswana Reaffirms Support for ICC, “Regrets” SA Decision. News24. http://www.news24.com/Africa/News/botswana-reaffirms-support-for-icc-regrets-sa-decision$\underline{20161026}$

The Free Dictionary. Sovereignty Immunity. http://legal-dictionary.thefreedictionary.com/Sovereign+Immunity

Wallis, W., \& Hollinger, P. (2008). Kagame Aide Faces Extradition to France. Financial Times. 
World Report (2015). European Union: Events of 2014.

http://www.hrw.org/world-report/2015/country-chapters/croatia-european-union-france-ger many-greece-hungary-italy

Zimbabwe News (2016). Mugabe Must Go Now: Ian Khama, President of Botswana. Zimbabwe News. http://www.zimnews.net/botswana-presi-khama-attacks-mugabe

Submit or recommend next manuscript to SCIRP and we will provide best service for you:

Accepting pre-submission inquiries through Email, Facebook, LinkedIn, Twitter, etc. A wide selection of journals (inclusive of 9 subjects, more than 200 journals)

Providing 24-hour high-quality service

User-friendly online submission system

Fair and swift peer-review system

Efficient typesetting and proofreading procedure

Display of the result of downloads and visits, as well as the number of cited articles Maximum dissemination of your research work

Submit your manuscript at: http://papersubmission.scirp.org/

Or contact ojps@scirp.org 